\title{
Al-Mg-Si 系合金の曲げ加工性に及ぼす時効析出物の影響*
}

\author{
中西 英貴 $* *$. 浅野 峰生**.吉田 英雄 $* *$
}

Journal of The Japan Institute of Light Metals, Vol. 64, No. 6 (2014), 235-240

(c) 2014 The Japan Institute of Light Metals

\section{Effect of aging precipitates on the bendability of an $\mathrm{Al}-\mathrm{Mg}-\mathrm{Si}$ alloy*}

\author{
Hidetaka NAKANISHI** ${ }^{*}$ Mineo ASANO** and Hideo YOSHIDA**
}

\begin{abstract}
$\mathrm{Al}-\mathrm{Mg}-\mathrm{Si}$ alloys are usually applied a $\mathrm{T} 4$ temper as the plate material for automobile bodies, because of necessity of a high bake hardening property. Many reports about the improvement in the bendability of Al-Mg-Si alloys applied a T4 temper has been published, because they easily crack during the hemming process. On the other hand, $\mathrm{Al}-\mathrm{Mg}-\mathrm{Si}$ alloys applied T6 and $\mathrm{T} 7$ tempers are used for the material of wiring plates and heat radiation devices. A high electrical conductivity and good bendability are necessary for these devices. In this paper, the effect of the aging conditions on the bendability was investigated. As a result, the bendability at the T6 temper significantly decreased. The bendability under the aging temper, and over the aging temper was better than that at the T6 temper. Specimens treated by natural-aging at high temperature before the T6 temper easily cracked during the bending test. It was postulated that the formation of shear bands was significant and the bendability decreased during the bending test under the high density and finely $\beta^{\prime \prime}$ phase precipitate conditions.
\end{abstract}

(Received January 15, 2014 Accepted March 30, 2014)

Keywords: $A l-M g-S i$ alloy, bendability, $\beta^{\prime \prime}$ phase, shear band

\section{1. 緒言}

近年, $\mathrm{CO}_{2}$ 排出量削減等の地球環境保全の観点から, 自動 車用材料の軽量化が積極的に進められており，その中でも自 動車ボディ用板材として $\mathrm{Al}-\mathrm{Mg}-\mathrm{Si}$ 系合金の適用が拡大して いる。 $\mathrm{Al}-\mathrm{Mg}-\mathrm{Si}$ 系合金は熱処理型の合金であり，熱処理に より時効硬化する特性を有する。そのため, T4 調質材をプ レス加工およびへミングを行った後, 塗装焼付け处理を行っ た際に時効硬化（ベークハード）させることで, 強度を向上 させることができる。 $\mathrm{Al}-\mathrm{Mg}-\mathrm{Si}$ 系合金のT4調質材はへミン グ時に割れが発生しやすいため, 曲げ加工性の改善が課題の 一つとして挙げられ，これまでに多くの研究開発が行われて きた ${ }^{1) \sim 4}$ 。一方，ハイブリッド車や電気自動車の普及に伴 い，自動車用の導電部材や放熱部材としても $\mathrm{Al}-\mathrm{Mg}-\mathrm{Si}$ 系合 金の適用が拡大している。これらの部材には高い電気伝導性 や熱伝導性が求められるため, T6〜 T7 調質の材料が使用さ れている。しかし，T4調質材と比較して，T6〜 T7 調質材の 曲げ加工性に関する研究報告例は少なく，曲げ加工性に及ぼ す溶体化処理後の自然時効㧍よび人工時効の影響は明らかに されていない。そこで，本研究では $\mathrm{Al}-\mathrm{Mg}-\mathrm{Si}$ 系合金の曲げ 加工性に及ぼす溶体化処理後の自然時効およびその後の人工 時効条件の影響を調查し, 時効析出相が曲げ加工性に及ぼす 影響について考察した。

\section{2. 実験方法}

Table 1 に示す化学成分を有する板厚 $2.0 \mathrm{~mm}$ の 6101（板 厚 $2.0 \mathrm{~mm}$ ）の冷間圧延板を供試材として用いた。まず，塩 浴炬にて $823 \mathrm{~K}-50 \mathrm{~s}$ の溶体化処理を行い, その後水中に焼入 れを行った。溶体化処理後 $5 \mathrm{~min}$ 以内に $278 \mathrm{~K}, 293 \mathrm{~K}, 303 \mathrm{~K}$ の恒温槽へ投入し, $7 \mathrm{~d}$ の自然時効処理を行い, 次いで大気 炉を用いて $50^{\circ} \mathrm{C} / \mathrm{h}$ の昇温速度にて $463 \mathrm{~K}-0 \sim 48 \mathrm{~h}$ の人工時効 処理を行った。以降, $278 \mathrm{~K}, 293 \mathrm{~K}, 303 \mathrm{~K}$ にて $7 \mathrm{~d}$ の自然時効 処理を行った試験片を $278 \mathrm{~K}-7 \mathrm{~d}$ 材, $293 \mathrm{~K}-7 \mathrm{~d}$ 材, $303 \mathrm{~K}-7 \mathrm{~d}$

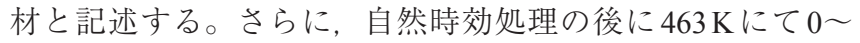
$48 \mathrm{~h}$ の人工時効処理を行った試験片を $463 \mathrm{~K}-0 \mathrm{~h}$ 材, $463 \mathrm{~K}-1 \mathrm{~h}$ 材，‥,463 K-48h材と記述する。それぞれの熱処理を行った 試験片について, 導電率, 曲げ加工性㧍よび引張性質を調 査した。導電率は渦電流方式の導電率測定機（日本フェル スター製のシグマテスト）を用いて，298Kの室温環境下に て測定した。曲げ加工性はJIS-Z-2248に記載の押曲げ法に準 拠した密着曲げにより評価し，予備曲げは内側半径 $1.0 \mathrm{~mm}$,

Table 1 Chemical composition of the specimens.

$(\operatorname{mass} \%)$

\begin{tabular}{c|c|c|c}
\hline \hline $\mathrm{Mg}$ & $\mathrm{Si}$ & $\mathrm{Fe}$ & $\mathrm{Al}$ \\
\hline 0.59 & 0.44 & 0.36 & $\mathrm{Bal}$. \\
\hline
\end{tabular}

*軽金属学会第 124 回春期大会（2013 年 5 月）にて一部発表。

**株式会社UACJ技術開発研究所名古屋センター（† †55-8670 愛知県名古屋市港区千年 3-1-12)。UACJ Corporation Nagoya Center, Research \& Development Division (3-1-12, Chitose, Minato-ku, Nagoya-shi, Aichi 455-8670). E-mail: nakanishi-hidetaka@uacj.co.jp 
曲げ方向は圧延方向に対して直角とした。引張性質はJIS5 号 試験片に成形加工した後，JIS-Z-2241に準拠した引張試験に より評価した。また，析出物の同定については示差走査型熱 量分析 (以下, DSC 分析), 析出物の分布状態は透過型電子 顕微鏡（以下，TEM）を用いて調査した。DSC分析は昇温 速度 $20 \mathrm{~K} / \mathrm{min} に て$ 実施した。

\section{3. 実 験 結 果}

Fig. 1 に冷間圧延板および溶体化処理後の圧延平行断面 (LST 面）の光学顕微鏡組織をそれぞれ示す。溶体化処理によ り，全面再結晶組織を呈している。以後議論する各種試験片 は溶体化処理までは同条件で作製し，溶体化処理以降の自然 時効・人工時効条件を変化させた試験片であるため，結晶粒 径や集合組織に有意差はないものとして考察した。

Fig. 2 に引張性質と自然時効温度および人工時効時間の関 係を示す。自然時効温度が高いほど, 人工時効後の引張強 さおよび耐力が高かった。また，3水準の温度にて自然時効 処理を施した試験片はいずれも $4 \sim 8 \mathrm{~h}$ の人工時効処理により ピーク強度に達した後，強度が低下した。一方，伸びは人工 時効初期に低下し，人工時効時間の増加による変化はごくわ ずかにしかみられなかった。

Fig. 3 に人工時効処理時間と導電率の関係を示す。人工時 効時間が増加するにつれて，導電率は単調に増加した。これ は人工時効処理時間の増加とともに析出が進行し，材料中の 固溶元素量が単調に減少していることを示していると考えら れる ${ }^{5)}$ 。なお，本合金系の場合， $463 \mathrm{~K}$ 人工時効処理におい て析出挙動を示す固溶元素は $\mathrm{Mg}$ および $\mathrm{Si}$ と考えられる ${ }^{6)}$ 。

Fig. 4 に曲げ加工性と自然時効温度および人工時効時間の 関係を示す。曲げ割れの程度が顕著であり，曲げ加工性の低 いものから順番に4/3.5/3/2.5/2/1.5/1/0.5/0 とし，4から 0 まで 0.5 ごとの9段階のランクにて評価した。ランク $3.5,2.5,1.5$, 0.5 についてはそれぞれランク 4 と 3 の間，3 3 との間， 2 と 1 の間， 1 と0の間の曲げ加工性であるとして定義した。同じ 人工時効時間で比較すると, 自然時効温度が高いほど，曲 げ加工性は低かった。また，種々の自然時効処理を施した いずれの試験片も，ピーク強度を示した $4 \mathrm{~h}$ 材または $8 \mathrm{~h}$ 材 (a) Tensile strength

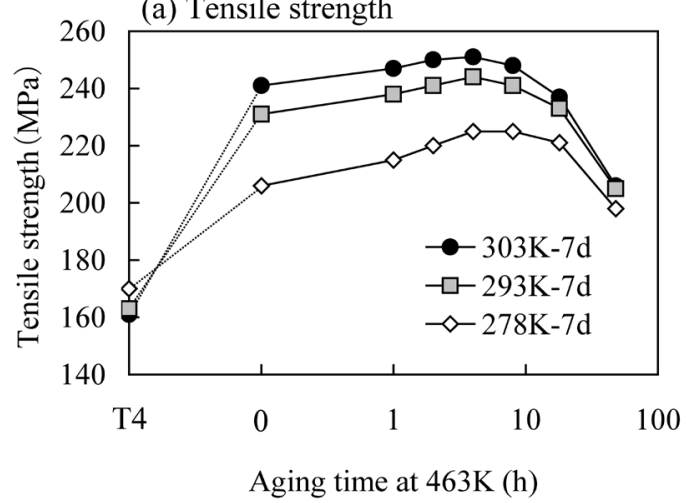

(b) Yield stress

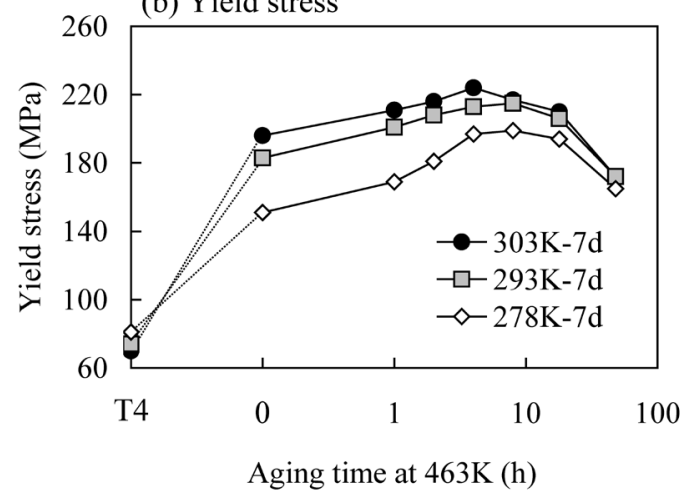

(c) Elongation

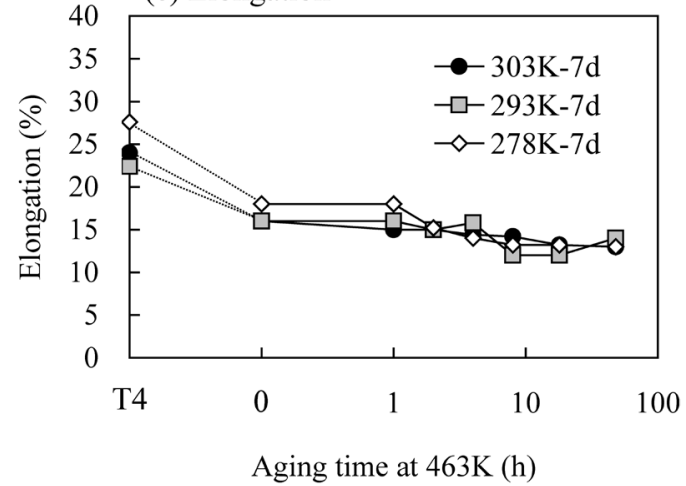

Fig. 2 Tensile properties of the specimens aged at $463 \mathrm{~K}$. (a) As-rolled

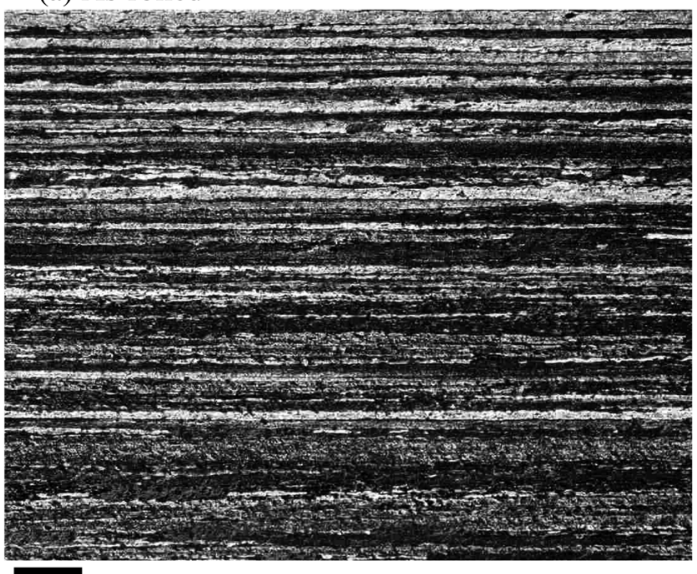

$100 \mu \mathrm{m}$ (b) After SHT at $823 \mathrm{~K}$ for $50 \mathrm{~s}$

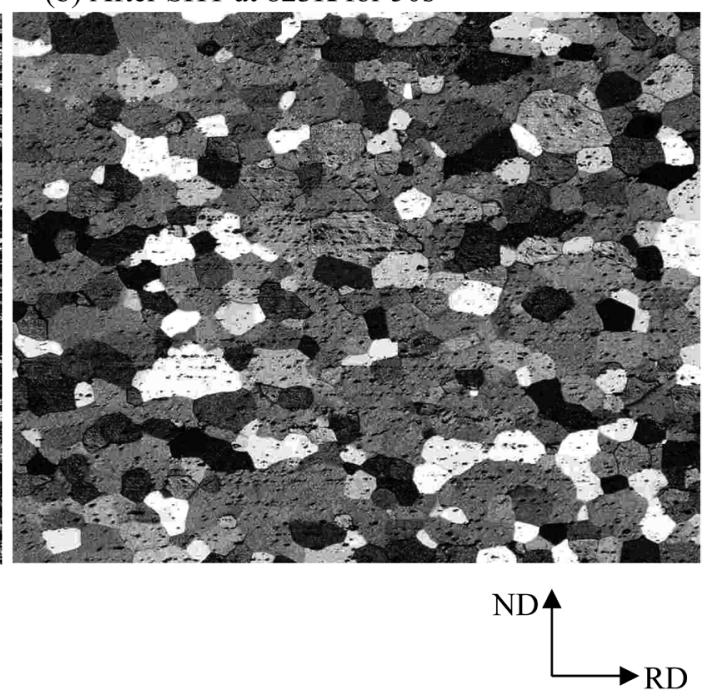

Fig. 1 Optical microstructures of cross section parallel to the rolling direction (a) as-rolled, and (b) after SHT at $823 \mathrm{~K}$ for $50 \mathrm{~s}$. 
において曲げ加工性が最も低下し，人工時効処理短時間側 の亜時効域および長時間側の過時効域において曲げ加工性 は改善した。Fig. 5 に曲げ試験片断面の光学顕微鏡組織を示

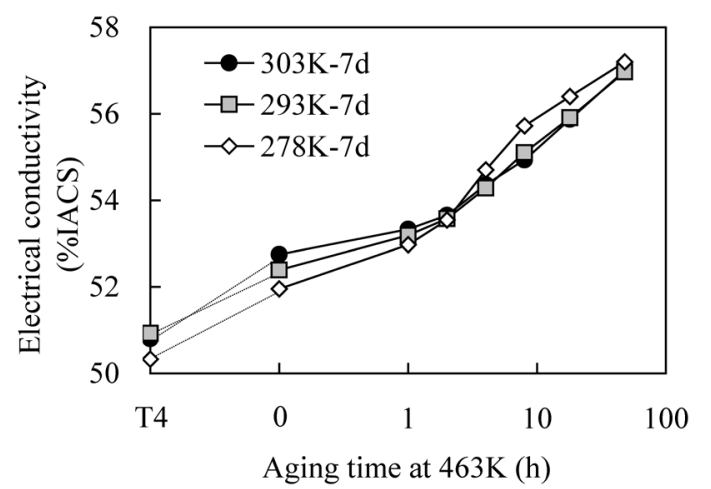

Fig. 3 Electrical conductivity of the specimens aged at $463 \mathrm{~K}$.

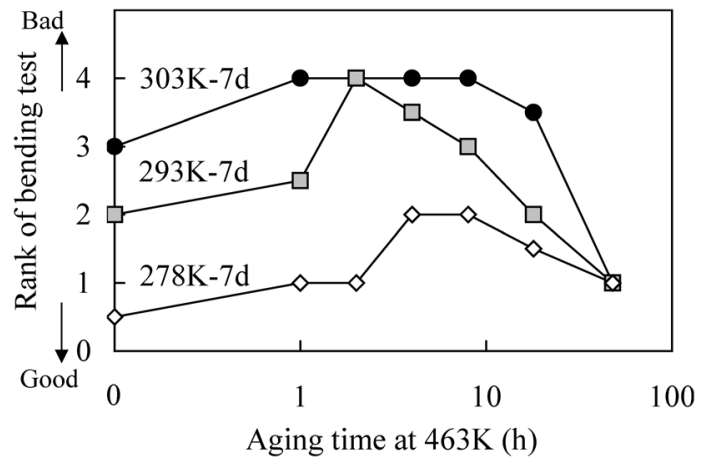

Fig. 4 Ranks of the bendability of the specimens aged at $463 \mathrm{~K}$.
す。曲げ加工性の低かった $303 \mathrm{~K}-7 \mathrm{~d}$ の自然時効材について， $463 \mathrm{~K}-0 \mathrm{~h}$ (亜時効域), $463 \mathrm{~K}-4 \mathrm{~h}$ (ピーク時効付近）の人工 時効処理を施した試験片では，曲げ加工外側の表層で発生し た割れが結晶粒をまたいで直線的に試験片内部まで進展して いた。これは，曲げ加工時に発生したせん断帯に沿って割れ が進展したためと考えられる ${ }^{1)}$ 。また，割れの発生していな い試験片において，表層に発生したくびれの直下にせん断帯 と考えられる複数の結晶粒にまたがる局所的な変形が観察さ れた。

Fig. 6 に278K-7d 自然時効後の 463K-4h 材, $303 \mathrm{~K}-7 \mathrm{~d}$ 自然時効後の $463 \mathrm{~K}-0 \mathrm{~h}$ 材， $4 \mathrm{~h}$ 材， $48 \mathrm{~h}$ 材それぞれについ て (100) $\mathrm{Al}$ 面 TEM明視野像を示す。いずれの視野において も, $\beta^{\prime \prime}$ 相と考えられる ${ }^{6)}$ 針状析出物が観察された。また, 人工時効条件が同じ $463 \mathrm{~K}-4 \mathrm{~h}$ 材については, 自然時効条件 が $303 \mathrm{~K}-7 \mathrm{~d}$ では数密度が約 1230 個 $/ \mu \mathrm{m}^{2}$ であり, $278 \mathrm{~K}-7 \mathrm{~d}$ 材 では約 930 個 $/ \mu \mathrm{m}^{2}$ であり, 人工時効前の自然時効温度が高い $303 \mathrm{~K}-7 \mathrm{~d}$ 材では高密度微細に析出していた。また, 人工時効 時間の増加に伴い，針状析出物の粗大化が観察された。

\section{4. 考察}

\section{1 曲げ加工性と強度の関係}

曲げ加工性には集合組織が大きく影響を及ぼす $\left.{ }^{4}\right)$ が，本 研究の試験片は前述したように，単一の溶体化処理条件によ り再結晶させた試験片を用いている。そのため, 結晶粒径 や集合組織に有意差はないと考えることができる。そこで, Fig. 7 に曲げ加工性と引張強さおよび耐力の関係を合せて示 す。引張強さが高いほど，曲げ加工性が低下する傾向がみら れた。しかし，詳細に比較すると同等の引張強さにおいても 曲げ加工性に有意差がみられる場合が存在する。したがっ て，引張強さに代表されるようなマク口的な材料情報である 機械的性質と曲げ加工性は一対一の対応関係にはないと考え (a) $278 \mathrm{~K}-7 \mathrm{~d}, 463 \mathrm{~K}-0 \mathrm{~h}$

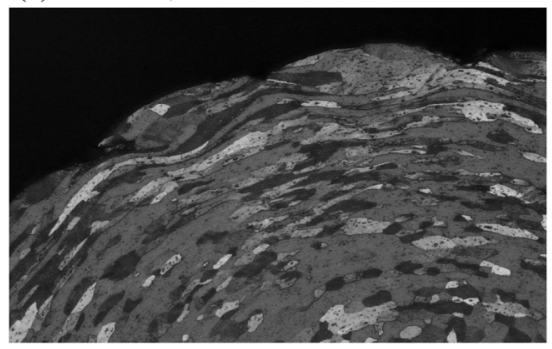

(d) $303 \mathrm{~K}-7 \mathrm{~d}, 463 \mathrm{~K}-0 \mathrm{~h}$

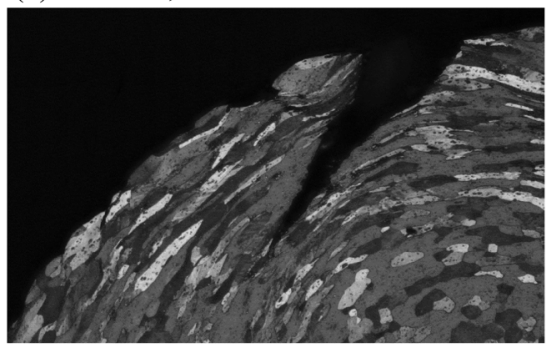

(b) $278 \mathrm{~K}-7 \mathrm{~d}, 463 \mathrm{~K}-4 \mathrm{~h}$

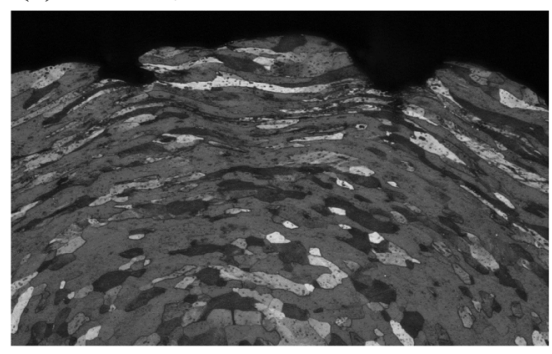

(e) $303 \mathrm{~K}-7 \mathrm{~d}, 463 \mathrm{~K}-4 \mathrm{~h}$

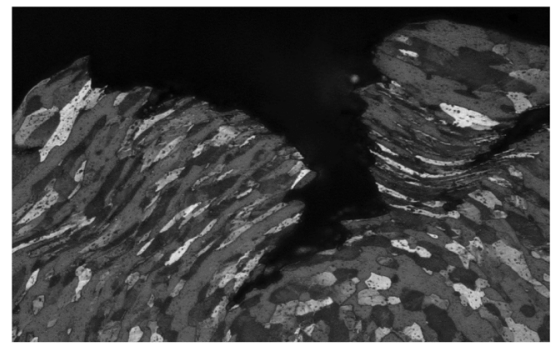

(c) $278 \mathrm{~K}-7 \mathrm{~d}, 463 \mathrm{~K}-48 \mathrm{~h}$

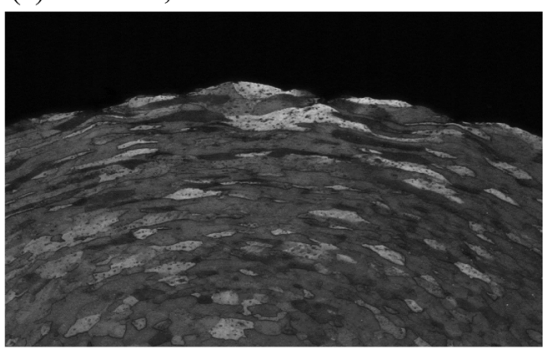

(f) $303 \mathrm{~K}-7 \mathrm{~d}, 463 \mathrm{~K}-48 \mathrm{~h}$

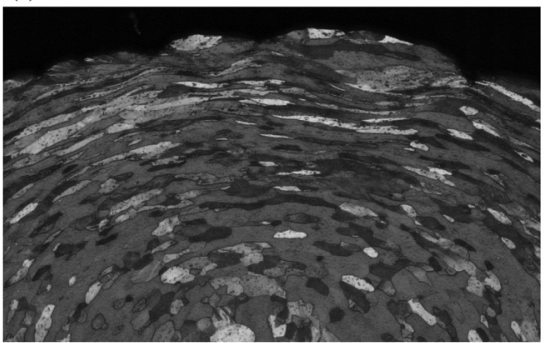

$200 \mu \mathrm{m}$

Fig. 5 Optical microstructures of the specimens after bending test aged at $278 \mathrm{~K}$ for $7 \mathrm{~d}$ followed $463 \mathrm{~K}$ for (a) $0 \mathrm{~h}$, (b) $4 \mathrm{~h}$, (c) $48 \mathrm{~h}$, and at $303 \mathrm{~K}$ for $7 \mathrm{~d}$ followed $463 \mathrm{~K}$ for (d) $0 \mathrm{~h}$, (e) $4 \mathrm{~h}$, (f) $48 \mathrm{~h}$. 
(a) $278 \mathrm{~K}-7 \mathrm{~d}, 463 \mathrm{~K}-4 \mathrm{~h}$

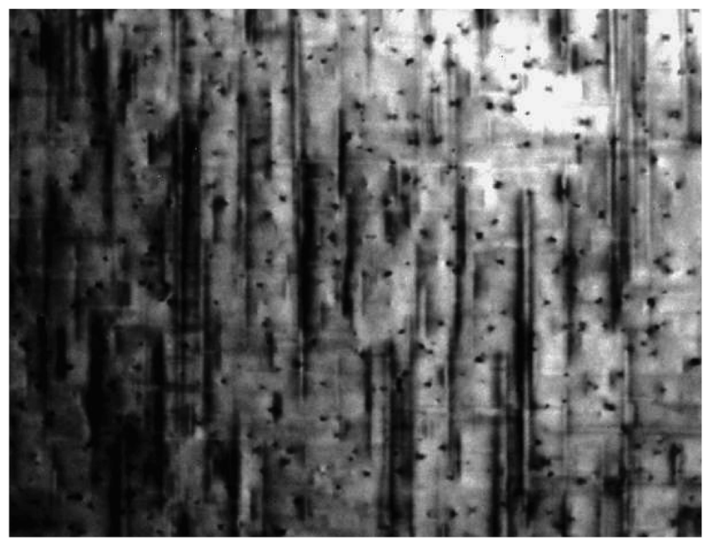

(c) $303 \mathrm{~K}-7 \mathrm{~d}, 463 \mathrm{~K}-4 \mathrm{~h}$

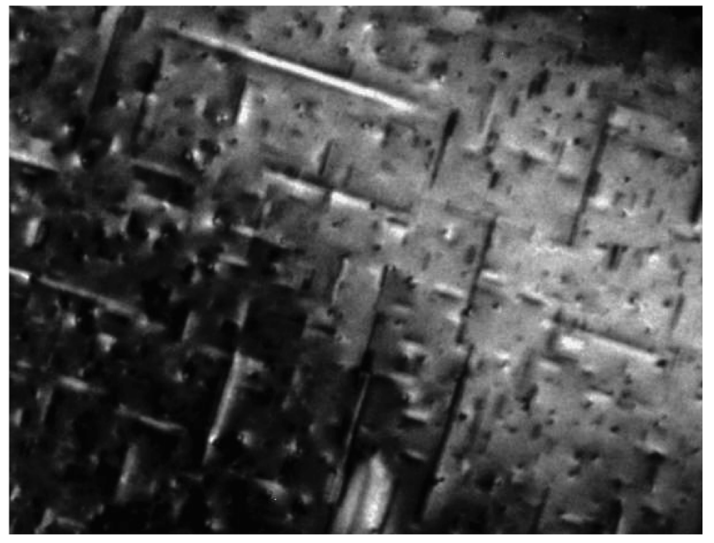

(b) $303 \mathrm{~K}-7 \mathrm{~d}, 463 \mathrm{~K}-0 \mathrm{~h}$

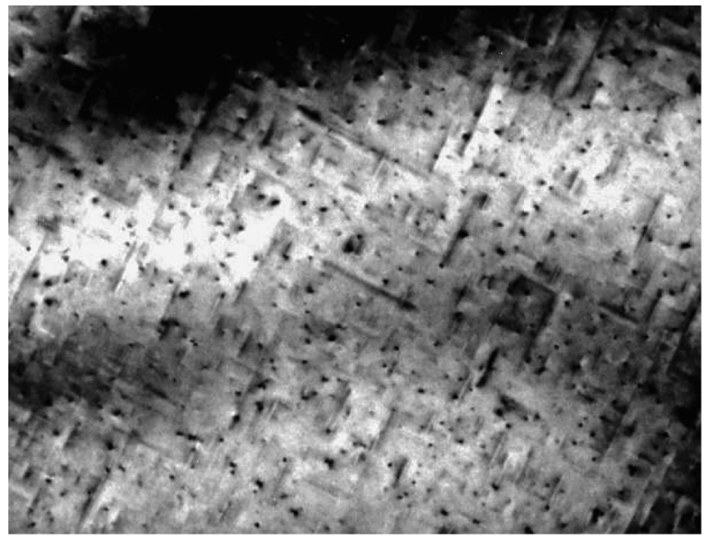

(d) $303 \mathrm{~K}-7 \mathrm{~d}, 463 \mathrm{~K}-48 \mathrm{~h}$

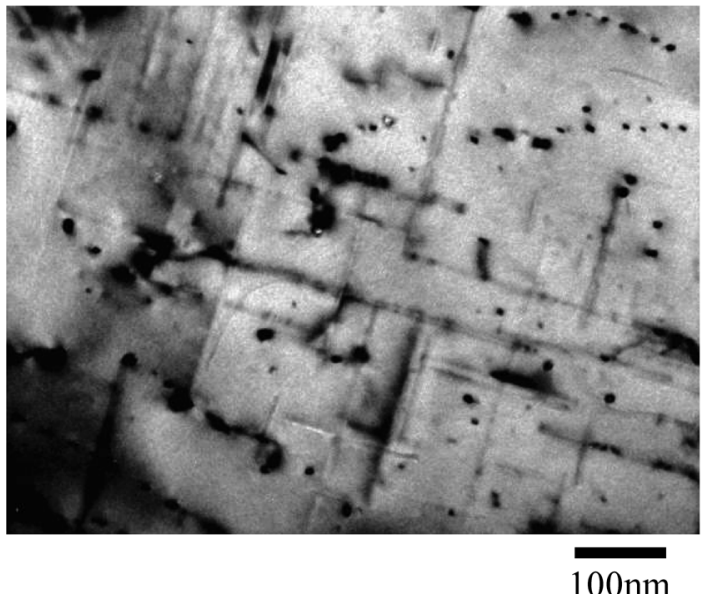

Fig. 6 TEM images of the specimens aged (a) at $278 \mathrm{~K}$ for $7 \mathrm{~d}$ followed at $463 \mathrm{~K}$ for $4 \mathrm{~h}$, and at $303 \mathrm{~K}$ for $7 \mathrm{~d}$ followed at $463 \mathrm{~K}$ for (b) $0 \mathrm{~h}$, (c) $4 \mathrm{~h}$, (d) $48 \mathrm{~h}$.
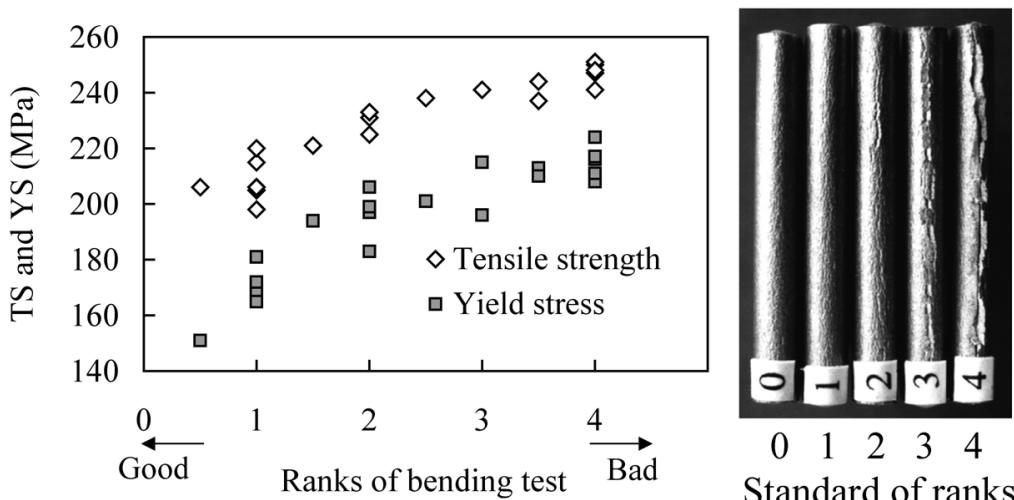

$\begin{array}{lllll}0 & 1 & 2 & 3 & 4\end{array}$

Standard of ranks

Fig. 7 Relationship between ranks of bending test and tensile strength or yield stress.

られる。そのため，ミクロ的な材料情報である材料組織との 対応を検討する必要がある。時効処理条件の違いに起因する 結晶粒径および集合組織に有意差はなく，人工時効時間とと もに固溶元素量も単調に減少することは前述のように明らか となっている。そこで, 以下の項では材料中の析出状態が曲 げ加工性に及ぼす影響を考察した。

\section{2 析出状態の調査}

4.2. 1 DSC 分析結果

各自然時効, 人工時効条件における析出相の種類と量を 調査するためにDSC 分析を行った。Fig. 8に 278K-7d および $303 \mathrm{~K}-7 \mathrm{~d}$ の自然時効後に $463 \mathrm{~K}-0 \sim 48 \mathrm{~h}$ の人工時効処理を行っ た試験片について, DSC分析を行った結果を示す。なお, 固 溶析出に伴う各ピークは, $500 \mathrm{~K}$ 付近がクラスタ溶解に伴う 吸熱反応 $(\mathrm{a}), 520 \mathrm{~K}$ 付近が主強化相である $\beta^{\prime \prime}$ 相の析出に伴 


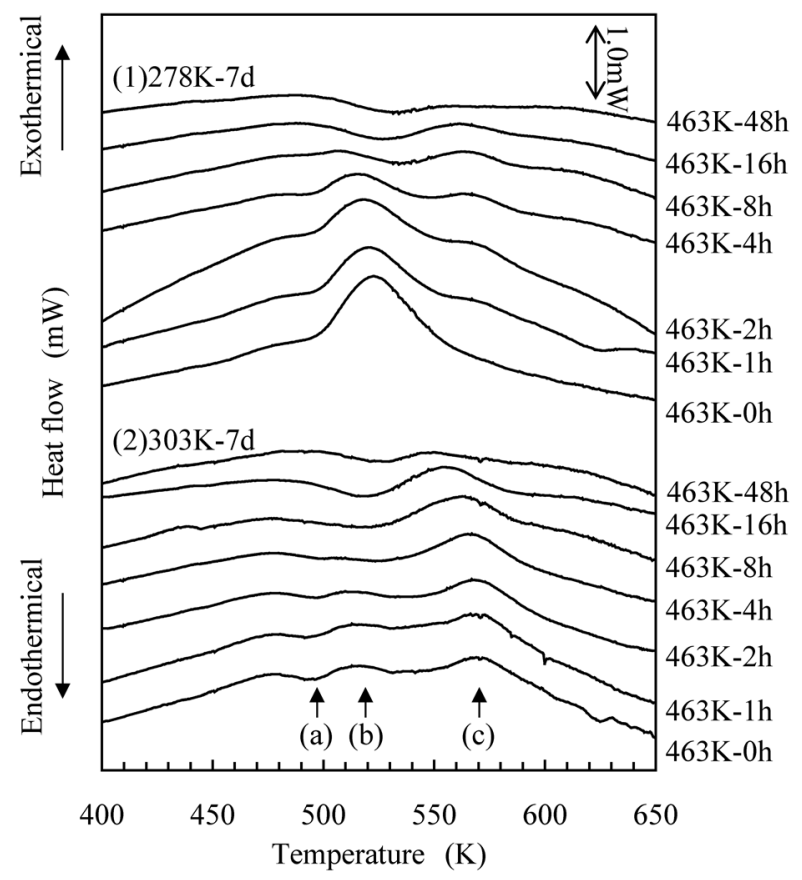

Fig. 8 DSC analysis of the specimens aged at (1) $278 \mathrm{~K}$ for $7 \mathrm{~d}$, and (2) at $303 \mathrm{~K}$ for $7 \mathrm{~d}$ followed at $463 \mathrm{~K}$ for $0 \sim 48 \mathrm{~h}$.

う発熱反応 $(\mathrm{b}), 570 \mathrm{~K}$ 付近が $\beta^{\prime}$ 相析出に伴う発熱反応 (c) と 考えられる ${ }^{7) \sim 9)}$ 。なお，自然時効中に生成するクラス夕は2 種類あるという報告例 ${ }^{10)}$ が多いが，本実験では 1 つのクラ ス夕溶解ピークのみが検出された。本研究では自然時効温度 が283〜303 K と低温であるため，高温で形成するクラス夕 2 はほとんど形成せず，クラスタ 1 が主として形成しているも のと考えられる。そのため, DSC 分析ではクラスタ 1 の吸熱 ピークのみが観察されたと考えられる。したがって，500K 付近のピーク (a) をクラスタの溶解に伴う吸熱反応として考 察した。

まず, $303 \mathrm{~K}-7 \mathrm{~d}$ の自然時効材について, $463 \mathrm{~K}-0 \mathrm{~h}$ 材, $1 \mathrm{~h}$ 材, $2 \mathrm{~h}$ 材ではクラスタの溶解ピーク $(\mathrm{a}), \beta^{\prime \prime}$ 相の析出ピーク $(\mathrm{b})$ および $\beta^{\prime}$ 相の析出ピーク (c)がすべて確認できた。特に $\beta^{\prime \prime}$ 相 の析出ピーク (b) は人工時効が進むにつれてピーク位置が低 温側へシフトしていた。したがって，少なくとも $463 \mathrm{~K}-1 \mathrm{~h}$ 材 から $2 \mathrm{~h}$ 材へ向かってクラス夕の成長もしくは $\beta^{\prime \prime}$ 相の析出が

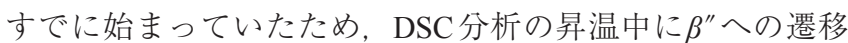
が生じやすくなり， $\beta^{\prime \prime}$ 相の析出ピーク $(\mathrm{b})$ の低温側へのシフ トが生じたと考えられる。一方で， $\beta^{\prime}$ 相の析出ピーク (c)に シフトはみられなかった。これは, DSC分析の昇温中の $\beta^{\prime \prime}$ 相から $\beta^{\prime}$ 相への遷移のしやすさは変わらないためと推察さ れ， $463 \mathrm{~K}-0 \sim 2 \mathrm{~h}$ の亜時効域では $\beta^{\prime \prime}$ 相はほとんど析出してい なかったと考えられる。次に，463K-4h材，8h材および $16 \mathrm{~h}$ 材では $\beta^{\prime}$ 相の析出ピーク (c)のみがみられ, クラス夕の溶解 ピーク (a)および $\beta^{\prime \prime}$ 相の析出ピーク (b) は検出されなかった。 したがって，463 K-4〜16hのピーク時効〜過時効域では材料 中にクラスタはほとんど存在しなかったと考えられる。ま た， $\beta^{\prime}$ 相の析出ピーク (c)のみがみられ，ピーク位置も人工 時効時間の増加とともに低温側へシフトしていることから, $463 \mathrm{~K}-4 \sim 16 \mathrm{~h}$ の人工時効中に $\beta^{\prime \prime}$ 相の析出が進行し, 人工時 効時間の増加とともにDSC 分析の昇温中の $\beta^{\prime}$ 相への遷移が
Table 2 Kinds of phases and their volume fraction of precipitation.

\begin{tabular}{c|c|c|c|c}
\hline \hline \multirow{2}{*}{$\begin{array}{c}\text { Natural aging } \\
\text { condition }\end{array}$} & $\begin{array}{c}\text { Artificial } \\
\text { aging time at } \\
463 \mathrm{~K}\end{array}$ & \multicolumn{3}{|c}{$\begin{array}{c}\text { Phase and volume fraction of } \\
\text { precipitation }\end{array}$} \\
\cline { 2 - 5 } & $0 \mathrm{~h}$ & $\bigcirc$ & - & $(-)$ \\
\hline \multirow{5}{*}{$278 \mathrm{~K}-7 \mathrm{~d}$} & $1 \mathrm{~h}$ & $\bigcirc$ & $\triangle$ & $(-)$ \\
& $2 \mathrm{~h}$ & $\triangle$ & $\triangle$ & $(-)$ \\
& $4 \mathrm{~h}$ & $\triangle$ & $\triangle$ & $(\triangle)$ \\
& $8 \mathrm{~h}$ & - & $\triangle$ & $(\triangle)$ \\
& $16 \mathrm{~h}$ & - & $\triangle$ & $(\triangle)$ \\
& $48 \mathrm{~h}$ & - & - & $(\bigcirc)$ \\
\hline \multirow{5}{*}{$303 \mathrm{~K}-7 \mathrm{~d}$} & $0 \mathrm{~h}$ & $\bigcirc$ & $\triangle$ & $(-)$ \\
& $1 \mathrm{~h}$ & $\triangle$ & $\triangle$ & $(-)$ \\
& $2 \mathrm{~h}$ & $\triangle$ & $\triangle$ & $(-)$ \\
& $4 \mathrm{~h}$ & - & $\bigcirc$ & $(\triangle)$ \\
& $8 \mathrm{~h}$ & - & $\bigcirc$ & $(\triangle)$ \\
& $16 \mathrm{~h}$ & - & $\bigcirc$ & $(\triangle)$ \\
& $48 \mathrm{~h}$ & - & - & $(\bigcirc)$ \\
\hline
\end{tabular}

〈Symbols〉 $\bigcirc$ : much, $\triangle$ : existent, —: little or nothing, ( ): guess

生じやすくなったものと考えられる。最後に $463 \mathrm{~K}-48 \mathrm{~h}$ 材で はいずれのピークもほとんど検出されなかったため, 人工時 効処理 $48 \mathrm{~h}$ ではクラスタ, $\beta^{\prime \prime}$ 相はほとんど存在せず, $\beta^{\prime}$ 相が 主な析出相だったと考えられる。

続いて，278K-7dの自然時効材について，463K-0h材では $\beta^{\prime \prime}$ 相の大きな析出ピーク (b)のみがみられた。したがって, クラスタが形成されており, DSC分析の昇温中に $\beta^{\prime \prime}$ 相へ遷 移する量が多かったものと推察できる。しかし，278K自然 時効材は $303 \mathrm{~K}$ 自然時効材と比較して低温の自然時効である ため, $303 \mathrm{~K}$ 自然時効材よりも溶質原子量が多いことも $\beta^{\prime \prime}$ 相 析出ピークが大きかった原因の一つである可能性が考えら れる。なお, クラス夕の溶解ピークもみられるはずである が, $\beta^{\prime \prime}$ 相の大きな析出ピークの肩に隠れているために確認 できなかったと考えられる。次に $463 \mathrm{~K}-1 \mathrm{~h}$ 材, $2 \mathrm{~h}$ 材および $4 \mathrm{~h}$ 材では $\beta^{\prime \prime}$ 相の析出ピーク (b) および $\beta^{\prime}$ 相の析出ピーク (c) が検出された。人工時効時間の増加とともに $\beta^{\prime \prime}$ 相の析出ピー クが減少し， $\beta^{\prime}$ 相の析出ピークが増加していることから, 人 工時効時間の増加とともにクラスタから $\beta^{\prime \prime}$ 相への遷移が進 んでいるものと考えられる。次に $463 \mathrm{~K}-8 \mathrm{~h}$ 材および $16 \mathrm{~h}$ 材 では， $\beta^{\prime}$ 相の析出ピーク (c)のみがみられたため, クラス夕 の存在量は少なく, 主に $\beta^{\prime \prime}$ 相が析出していたと考えられる。 最後に $463 \mathrm{~K}-48 \mathrm{~h}$ 材ではいずれのピークもほとんど検出され なかったため, クラス夕, $\beta^{\prime \prime}$ 相はほとんど存在せず, $\beta^{\prime}$ 相が 主な析出相だったと考えられる。

以上のDSC分析の結果から, クラスタ, $\beta^{\prime \prime}$ 相および $\beta^{\prime}$ 相 の存在量と自然時効温度および人工時効処理時間の関係を定 性的に Table 2 によめる。 $278 \mathrm{~K}-7 \mathrm{~d}$ の自然時効材はクラス 夕が $463 \mathrm{~K}-4 \mathrm{~h}$ 材まで残存しており $\beta^{\prime \prime}$ 相は主に $463 \mathrm{~K}-1 \sim 16 \mathrm{~h}$, $\beta^{\prime}$ 相は $463 \mathrm{~K}-48 \mathrm{~h}$ 材に拈いて存在していると考えられる。ま た $303 \mathrm{~K}-7 \mathrm{~d}$ の自然時効材については, クラスタは $463 \mathrm{~K}-2 \mathrm{~h}$ 材までしか残存しておらず， $\beta^{\prime \prime}$ 相は $463 \mathrm{~K}-0 \sim 16 \mathrm{~h}, \quad \beta^{\prime}$ 相は 


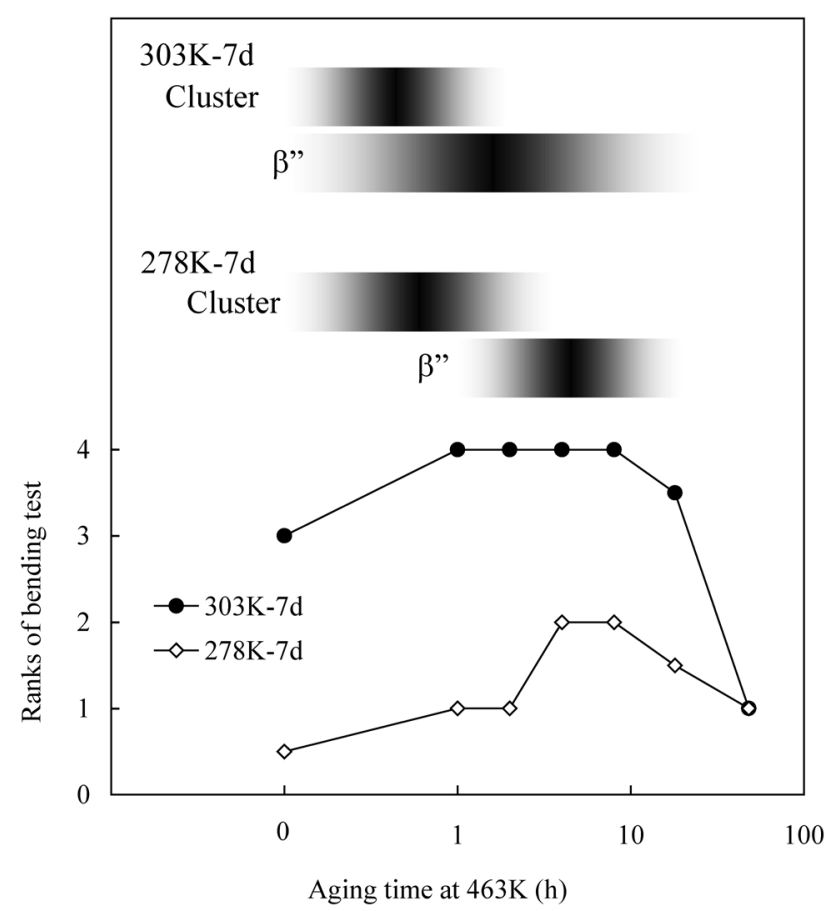

Fig. 9 The relationships between phases of precipitation and the bendability.

$463 \mathrm{~K}-48 \mathrm{~h}$ で存在していると考えられる。また， $\beta^{\prime}$ 相の析出 ピーク (c)の高さの比較から, $278 \mathrm{~K}-7 \mathrm{~d}$ 自然時効材よりも 303 K-7 d 自然時効材の方が， $\beta^{\prime \prime}$ 相の形成量は多いと考えられ る。したがって，自然時効温度が高いほど， $\beta^{\prime \prime}$ 相が人工時 効の初期に析出し，析出量も多いと考えられる。

\subsection{2 析出物の分布状態と曲げ加工性の関係}

Fig. 9 にDSC 分析結果から存在が示唆されるクラスタおよ び $\beta^{\prime \prime}$ 相の存在状態と曲げ加工性結果を合せて示す。人工時 効処理によりクラスタから $\beta^{\prime \prime}$ 相への遷移がほぼ完了し, $\beta^{\prime \prime}$ 相が主な析出相となったときが最も曲げ加工性が低くなっ た。したがって，クラスタよりも $\beta^{\prime \prime}$ 相の存在とその分布状 態が曲げ加工性に大きく影響を及ぼしていると考えられる。 これは, 自然時効温度が高いほど, $\beta^{\prime \prime}$ 相が微細高密度かつ 析出量も多くなり，曲げ加工性が低くなることからも支持さ れる。

曲げ割れがせん断帯を伝播した形態であることを考慮する と, $\beta^{\prime \prime}$ 相が高密度微細に存在することによりせん断帯が形
成しやすくなったと考えられる。曲げ加工中の転位と析出物 の相互作用が大きいほど，材料の局所な変形であるせん断帯 の形成が生じやすくなると考元られるが, 今後詳細な検討が 必要である。

\section{5. 結言}

$\mathrm{A} 1-\mathrm{Mg}-\mathrm{Si}$ 系（6101）合金の泠間圧延板を $823 \mathrm{~K} に て 50 \mathrm{~s}$ の 溶体化処理挹よび焼入れを行った試験片を用いて, 自然時効 処理㧍よびその後に人工時効処理を施し, 曲げ加工性に及ぼ す時効析出物の影響を調查した結果，以下の知見を得た。

（1）ピーク時効近傍において曲げ加工性が低下し, 亜時 効域㧍よび過時効域において曲げ加工性は改善した。

（2）人工時効前の自然時効温度が高いほど，曲げ加工性 は低下した。

（3）自然時効温度が高いほど， $\beta^{\prime \prime}$ 相が人工時効の初期に 析出し, 析出量も多いと考元られる。

（4） クラスタよりも $\beta^{\prime \prime}$ 相の存在とその分布状態が曲げ加 工性に大きく影響を及ぼしていると考えられる。

（5） $\beta^{\prime \prime}$ 相が高密度微細に存在することによりせん断帯が 形成しやすくなったと考えられる。曲げ加工中の転位と析出 物の相互作用が大きいほど，材料の局所な変形であるせん断 帯の形成が生じやすくなると考えられるが，今後詳細な検討 が必要である。

\section{参 考 文 献}

1) 浅野峰生, 内田秀俊, 吉田英雄：軽金属, 52（2002）, 448452 .

2) 日比野旭, 村松俊樹, 佐賀 誠, 高田 健：軽金属, 53 (2003), 534-541.

3) 竹田博貴, 日比野旭, 高田健 : 軽金属, 60 (2010), 231236

4) 伊川慎吾, 浅野峰生, 黒田充紀, 吉田健吾：軽金属, 61 (2011), 53-59.

5）アルミニウム材料の基礎と工業技術，軽金属協会，(1998）, 342-344.

6）松田健二，池野 進：軽金属，53（2003），457-462.

7) A. K. Gupta and D. J. Lloyd: Met. Mater. Trans., 30A (1999), 879884.

8) 佐賀 誠, 佐々木行雄, 菊地正夫, 日比野旭, 松尾 守: 軽金 属, 53 (2003)， 516-522.

9）八太秀周, 松田眞一, 田中宏樹, 吉田英雄：軽金属, 59 (2009), 248-253.

10) 山田健太郎, 里 達雄, 神尾彰彦 : 軽金属, 51（2001）, 215221. 